\title{
Estimation of the genetic diversity of jabuticaba trees and association among fruit characters
}

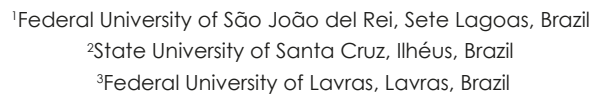

José Carlos Moraes Rufini' $\left(0\right.$, Miriã Cristina Pereira Fagundes ${ }^{2 *}\left(\mathbb{C}^{\circ}\right.$, Deniete Soares Magalhães ${ }^{3}(\mathbb{C}$, Alejandra Semiramis Albuquerque ${ }^{\circledR}$, Martha Cristina Pereira Ramos ${ }^{3}$, Ana Clara Pimenta Pereira ${ }^{\circledR}$

\begin{abstract}
The aim of this study was to evaluate the genetic dissimilarity of different jabuticaba tree accessions from Prudente de Moraes, Minas Gerais State, Brazil, based on fruit characters. The genetic diversity study was carried out based on characters evaluated in fruits, and with the elimination of redundant descriptors, nine characters were selected to estimate genetic divergence and perform clustering. The Standardized Mean Euclidian Distance was used as dissimilarity measure. The clustering methods used were Tocher and the nearest neighbor. Correlation analysis among characters was performed by Pearson correlation ( $p>0.05$ ). Accessions 4, 5, 7 and 12 have potential for in improvement programs aiming for productivity. The character that contributed most to the genetic diversity of the accessions were the soluble solids important for the processing industry and for fresh consumption. Genotypes showed variability for most characters analyzed showing the possibility of selection and identification of parents that will be used in future crossings.
\end{abstract}

Keywords: genetic improvement, phenotypic correlations, Myrciaria jabuticaba Berg

\section{Introduction}

Jabuticaba tree (Myrciaria jabuticaba Berg) is a fruit tree belonging to the Myrtaceae family, predominantly in the Atlantic Forest Biome, with secondary dispersion center in Paraguay and Argentina (Citadin et al., 2010), presenting great marketing potential, as it is much appreciated for fresh consumption as for industry (Danner et al., 2010). However, according to Salla et al. (2015), commercial orchards that cultivate the species are limited, mainly concentrated in the states of São Paulo, Minas Gerais and Goiás.

The insufficiency of commercial orchards is due to the lack of varieties recommended for this purpose, a fact related to the wide genetic variability and the predominance of crops in domestic orchards. Thus, genetic diversity studies are necessary in order to verify promising genotypes that can be inserted in commercial crops, and the genetic improvement of this fruit is an open and promising field of research.

Obtaining genotypes with desirable agronomic characteristics begins with the manipulation of plant genetic resources, and genetic variability is the starting point of any breeding program. Genetic diversity studies aimed at identifying parents suitable for crossbreeding search to obtain hybrids with greater heterotic effects, which provide greater segregation in recombination and enable the appearance of transgressive segregations (Cruz et al., 2014). In this context, the use of multivariate techniques has been shown to be useful as it allows multiple combinations of information within the experimental unit through discrimination, providing a holistic view of each genotype (Cruz et al., 2014; Moreira et al., 2009).

Several multivariate methods can be used to predict genetic diversity. Predictive methods of heterosis include those based on morphological, physiological or molecular differences, quantifying them in some 
measure of dissimilarity that expresses the degree of genetic diversity among parents (Cruz et al., 2014). Morphoagronomic characterization is a very important method, which is based on characters that are easy to detect and measure, with high heritability and little environmental influence (Costa et al., 2009). In this context, fruit and seed morphology and chemical pulp characterization are tools used to assist in pre-breeding programs of undomesticated species (Moura et al., 2013) and to identify genetic variability among individuals or accessions in a population (Almeida Júnior et al., 2014).

The evaluation of the contribution of each character to the discrimination of genotypes is also necessary to eliminate redundant descriptors, which may be excluded in the other selection stages, thus reducing data collection work, without reducing the characterization accuracy (Galate et al., 2012). Similarly, knowledge of character association can result in greater efficiency in selecting characters to be improved, as well as time and labor savings. Thus, analysis of characters of agronomic interest serves to support the selection of superior genotypes, and estimates of correlation coefficients among these characters allow indirect selection.

Thus, the aim of this work was to evaluate the genetic diversity and association among characters of agronomic interest in different jabuticaba tree accessions in order to identify promising materials for commercial use and for future breeding works.

\section{Material and Methods}

The experimental material was obtained from a domestic jabuticaba orchard, with approximately 16 years of implantation, in the municipality of Prudente de

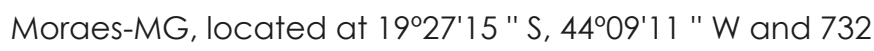
$\mathrm{m}$ a.s.I. The orchard with approximately 50 jabuticaba trees presents phenotypic variability, derived from the sexual propagation of materials collected from different locations. Among these plants, 17 were pre-selected for study based on their history, vigor, yield and phytosanitary status.

After the selection and marking of plants, fruits were collected in November 2011. Approximately 100 fruits per plant at physiological maturity stage were randomly collected and placed in plastic bags, identified and sent to the Laboratory of Plant Production - Federal University of São João Del Rei, campus of Sete Lagoas (Brazil) for analysis.

Fruit analyses were performed according to methodologies of Zenebon et al. (2008): fruit volume (FV), in $\mathrm{mL}$, obtained by immersing fruits in water in a millimeter beaker; fruit (FM), peel (PeM), pulp (PM) and seed (SM) masses, manually separated and weighed on a precision scale, expressed in grams; number of seeds (NS), obtained by direct counting; longitudinal (LD) and transverse (TD) diameters, measured with the aid of a digital caliper and expressed in $\mathrm{mm}$; total soluble solids (TSS), obtained by direct measurement of the filtered juice in digital refractometer, with results given in ${ }^{\circ}$ Brix. For $\mathrm{pH}$ and titratable acidity (TA) analyses, pulp was ground and homogenized in a 1:5 ratio $10 \mathrm{~g}$ of pulp diluted in $50 \mathrm{ml}$ of distilled water) and the filtrate was used for analysis. $\mathrm{pH}$ was determined using digital potentiometer, and titratable acidity was determined by titration with results expressed as percentage of citric acid per 100 grams of pulp. Pulp yield (PY) and total soluble solids / total titratable acidity ratio and longitudinal diameter/ transverse diameter (shape index) were also calculated, as well as fruit density $\left(\mathrm{g} \mathrm{cm}^{-3}\right)$.

Color was measured with the aid of the electronic colorimeter, with three readings of each of the two faces opposite to the equatorial region of each fruit. Readings were given in $L^{*}, a^{*}$ and $b^{*}$, where $L^{*}$ represents luminosity, $a^{*}$ represents variations from red to green sections of the light spectrum and $b$ * represents variations from yellow to blue sections of the light spectrum.

Results were submitted to descriptive analysis evaluating mean, standard deviation, variation coefficient and Pearson's correlations. To study the genetic divergence among accessions, the following methods were applied: standardized mean Euclidean distance; Cluster analysis by Tocher optimization method; Hierarchical method of the nearest neighbor, also evaluating the relative contribution of physicochemical characteristics in the observed variability among the 17 accessions, by the Singh's method (1981). Statistical and genetic analyses were performed using the computational resources of the Genes software (Cruz, 2006).

\section{Results and Discussion}

Fruit characterization

It is observed that there is potential variability among jabuticaba tree accessions that can be explored in the selection of superior individuals.

Average fruit mass was $4.28 \mathrm{~g}$, with minimum values of $2.94 \mathrm{~g}$ for accession 8 and maximum values of $5.22 \mathrm{~g}$ for accession 10 (Table 1). Therefore, high variation for fruit mass was observed. The values found were higher than those reported by Guedes et al. (2014) in the region of Diamantina, MG for the "Sabará" variety. However, values were lower to those found by Zerbielli et al. (2016) 
at a naturally occurring site in the region of Passo Fundo, RS, Brazil. Accessions 1, 2, 5, 10 and 13 presented higher fruit mass in the conditions of the Central region of Minas Gerais. These variations may be related to agroecological cultivation conditions, but most likely due to the genetic characteristics of the material.

For pulp, seed and peel mass, averages of $1.48 \mathrm{~g}$, $1.34 \mathrm{~g}$ and $1.46 \mathrm{~g}$ were observed, respectively. These results were lower, except for seed mass, than those found by Citadin et al. (2005) evaluating the quality of jabuticaba fruits during three years under full sun and shade system.
Pulp mass ranged from 0.70 to $2.02 \mathrm{~g}$, thus showing the possibility of selecting fruits with higher amount of pulp. For Moura et al. (2010) pulp mass is the most important parameter for economic exploitation, especially in fruit processing. Another important factor in jabuticaba fruits is the peel mass, which is an important residue of industrial interest used to produce jams and extracts designed for the beverage and ice cream industry (Rodrigues et al., 2015) due to its high levels of anthocyanins and phenolic compounds (Alezandro et al., 2013; Silva et al., 2014).

Table 1. Mean, standard deviation (SD) and coefficient of variation (CV) for fruit characters of jabuticaba tree accessions.

\begin{tabular}{|c|c|c|c|c|c|c|c|c|c|}
\hline Accessions & $\mathrm{FM}$ & PM & $S M$ & PeM & LD & TD & $\mathrm{SI}$ & PY & NS \\
\hline 1 & 4.92 & 1.72 & 1.80 & 1.4 & 18.87 & 19.24 & 0.98 & 35.00 & 1.65 \\
\hline 2 & 4.99 & 1.45 & 1.53 & 2.01 & 19.75 & 19.9 & 0.99 & 29.14 & 1.57 \\
\hline 3 & 4.05 & 1.42 & 1.28 & 1.35 & 18.27 & 18.67 & 0.98 & 35.07 & 1.57 \\
\hline 4 & 4.31 & 1.22 & 1.55 & 1.54 & 18.76 & 18.92 & 0.99 & 27.97 & 1.15 \\
\hline 5 & 5.15 & 1.90 & 1.41 & 1.84 & 19.42 & 19.96 & 0.97 & 36.86 & 1.52 \\
\hline 6 & 4.78 & 1.78 & 1.99 & 1.00 & 19.24 & 19.35 & 0.99 & 37.05 & 1.72 \\
\hline 7 & 4.71 & 1.97 & 1.43 & 1.31 & 19.07 & 19.34 & 0.99 & 41.67 & 1.42 \\
\hline 8 & 2.94 & 0.70 & 0.94 & 1.30 & 16.18 & 16.43 & 0.98 & 23.09 & 1.72 \\
\hline 9 & 3.88 & 1.31 & 1.16 & 1.40 & 17.66 & 18.03 & 0.98 & 33.92 & 1.10 \\
\hline 10 & 5.22 & 1.85 & 1.43 & 1.94 & 20.07 & 20.1 & 1.00 & 35.27 & 1.50 \\
\hline 11 & 3.79 & 1.31 & 1.00 & 1.48 & 17.88 & 18.32 & 0.98 & 34.25 & 1.45 \\
\hline 12 & 4.44 & 2.02 & 1.29 & 1.10 & 18.59 & 18.59 & 1.00 & 45.19 & 1.30 \\
\hline 13 & 4.99 & 1.70 & 1.26 & 2.03 & 19.60 & 19.79 & 0.99 & 34.15 & 1.55 \\
\hline 14 & 3.58 & 1.27 & 1.16 & 1.15 & 17.31 & 17.53 & 0.99 & 35.25 & 1.55 \\
\hline 15 & 3.92 & 1.31 & 1.31 & 1.30 & 18.18 & 18.37 & 0.99 & 33.46 & 1.42 \\
\hline 16 & 3.65 & 1.10 & 1.18 & 1.37 & 17.84 & 18.08 & 0.99 & 29.70 & 1.22 \\
\hline 17 & 3.46 & 1.12 & 1.04 & 1.30 & 17.65 & 17.68 & 1.00 & 32.34 & 1.60 \\
\hline Mean & 4.28 & 1.48 & 1.34 & 1.46 & 18.49 & 18.72 & 0.99 & 34.08 & 1.47 \\
\hline SD & 0.74 & 0.49 & 0.44 & 0.37 & 1.09 & 1.08 & 0.01 & 5.05 & 12.59 \\
\hline CV(\%) & 17.36 & 33.17 & 33.38 & 25.53 & 5.93 & 5.79 & 4.68 & 29.09 & 1.86 \\
\hline
\end{tabular}

Seed mass ranged from 0.94 to $1.80 \mathrm{~g}$. Accession 8 presented the smallest seed mass, but the highest number of seeds, resulting in smaller pulp mass. Regarding the number of seeds, $52.9 \%$ of accessions presented number of seeds above 1.50, an important characteristic for the species, since the main method for obtaining seedlings is still by seeds. However, although the production of many seeds favors species propagation, both fresh consumption market and processing industries prefer fruits with fewer seeds, since pulp is the main commercialization object.

Pulp yield varied from $23.09 \%$ to $45.19 \%$ in relation to fruit mass, with an average of $34.08 \%$. Forty-one percent of accessions have average pulp yield above $35 \%$. The values obtained in the present study are in agreement with results found by Lima et al. (2008), who observed average of 36\%; however, they differ from values reported by Guedes et al. (2014) and Zerbielli et al. (2016), who obtained average of $62.54 \%$ and $67.9 \%$, respectively.
Longitudinal and transverse diameter ranged from 16.18 to $20.07 \mathrm{~mm}$ and from 16.43 to $20.10 \mathrm{~mm}$, respectively. Most fruits analyzed, about $64.7 \%$, have fruits with longitudinal diameter larger than the average and $47 \%$ of fruits have transverse diameter larger than the average. Fruit diameter is a very useful physical index for fruits intended for fresh consumption market, since consumers generally prefer larger, attractive-looking fruits, being a restricted use parameter when intended for processing.

The fruit shape index ranged from 0.97 to 1.00 , characterizing rounded fruits. These values are consistent with those found by Guedes et al. (2014), who observed that fruit shape and diameter are important attributes for commercialization, as they affect attractiveness and, consequently, the choice of individual units of the product by the consumer.

Fruit volume ranged from 3.05 to $5.05 \mathrm{~cm}^{-3}$, with average of $3.98 \mathrm{~cm}^{-3}$ (Table 2). Fruit volume refers to its 
size, that is, the larger the fruit, the easier and faster its harvest, requiring less labor and, consequently, reducing production costs, in addition to being more attractive for fresh consumption.

Table 2. Mean, standard deviation (SD) and coefficient of variation (CV) for fruit characters of jabuticaba tree accessions.

\begin{tabular}{|c|c|c|c|c|c|c|}
\hline Accessions & $\mathrm{FV}$ & FD & $\mathrm{pH}$ & TA & TSS & Ratio \\
\hline 1 & 4.43 & 1.11 & 3.62 & 1.13 & 11.93 & 11.02 \\
\hline 2 & 4.25 & 1.19 & 3.90 & 0.9 & 8.68 & 9.77 \\
\hline 3 & 3.7 & 1.09 & 3.65 & 0.68 & 9.18 & 14.22 \\
\hline 4 & 3.9 & 1.11 & 3.58 & 0.88 & 10.65 & 12.24 \\
\hline 5 & 4.95 & 1.05 & 3.65 & 0.84 & 10.8 & 13.2 \\
\hline 6 & 4.3 & 1.11 & 3.46 & 0.94 & 9.03 & 9.63 \\
\hline 7 & 5.05 & 0.94 & 3.63 & 0.84 & 11.78 & 14.53 \\
\hline 8 & 3.05 & 1.02 & 3.62 & 1.10 & 9.5 & 8.88 \\
\hline 9 & 3.58 & 2.25 & 4.16 & 0.8 & 11.25 & 14.28 \\
\hline 10 & 4.83 & 1.08 & 3.54 & 0.74 & 10.43 & 14.42 \\
\hline 11 & 3.48 & 1.09 & 3.51 & 1.02 & 9.65 & 9.64 \\
\hline 12 & 4.15 & 1.07 & 3.63 & 0.75 & 11.73 & 16.37 \\
\hline 13 & 4.53 & 1.10 & 3.71 & 0.92 & 10.08 & 11.3 \\
\hline 14 & 3.18 & 1.13 & 3.51 & 1.04 & 13.13 & 13.12 \\
\hline 15 & 3.85 & 1.03 & 3.24 & 1.07 & 10.85 & 11.58 \\
\hline 16 & 3.35 & 1.09 & 3.25 & 0.95 & 11.53 & 12.5 \\
\hline 17 & 3.15 & 1.10 & 3.37 & 1.22 & 9.53 & 7.92 \\
\hline Mean & 3.98 & 1.15 & 3.59 & 0.93 & 10.57 & 12.04 \\
\hline SD & 0.79 & 0.29 & 0.22 & 0.21 & 1.32 & 3.37 \\
\hline $\mathrm{CV}(\%)$ & 19.89 & 1.09 & 8.06 & 23.48 & 12.56 & 28.01 \\
\hline
\end{tabular}

According to Perfeito et al. (2015), fruit density is a feature of high importance in fruit sorting techniques. In the present work, the average density was $1.15 \mathrm{~g} \mathrm{~cm}^{-3}$, with accessions 9 and 7 showing the highest and lowest density, respectively.

For pulp chemical characteristics, $\mathrm{pH}$ ranged from 3.24 to 4.16 with average of 3.59. Zerbielli et al. (2016) and Guedes et al. (2014) obtained similar pH variation (3.33 - 4.04) and (3.11 - 3.93), respectively. The average titratable acidity was $0.93 \%$ citric acid. These results are similar to found by Guedes et al. (2014) who observed an average of $0.86 \%$ citric acid and higher than values found by Zerbielli et al. (2016) who found average value of $0.59 \%$ citric acid.

The total soluble solids content was $10.57^{\circ}$ Brix, nine accessions $(1,4,5,7,9,12,14,15$ and 16) presented higher than average soluble solids values. Guedes et al. (2014) observed soluble solids values higher than those found in this study $14.52^{\circ}$ Brix. The relationship between soluble solids and titratable acidity (ratio) ranged from 7.92 to 16.37. These values were lower than those found by Guedes et al. (2014) (18.77) and Zerbielli et al. (2016) (30.9). The ratio is considered as a criterion for flavor evaluation in various fruits, in addition to being indicative of the ripening level and the degree of sweetness.

Luminosity data obtained averages of 24.94 for fruit peel and 26.12 for fruit pulp (Table 3). This coordinate varies from 0 to 100, ranging from completely black to completely white and indicates the color luminosity or clarity, and is related to fruit freshness. Note that values for both were close, indicating darker color, which is characteristic of the fruit.

For coordinate $a^{*}$, which indicates color variation from green to red, positive values are observed, therefore close to the coordinate. This result indicates little influence of red color on fruit pulp and peel. For the $b^{*}$ coordinate, which indicates color variation from blue to yellow, positive and higher values for pulp in relation to peel are observed, which allows us inferring that there is greater interference of the yellow color in pulp than in peel.

Variation coefficients were below $30 \%$, which is considered good for agronomic experiments (Gomes, 2009) and indicates low interaction of these characters with the environment, demonstrating good accuracy of evaluations, except for fruit mass, which presented variation coefficient of $33 \%$. The lower values for fruit diameters and seed mass indicate lower interaction of these characters with the environment when compared to the other evaluated characters. Larger standard deviations for longitudinal and transverse diameters, $\mathrm{pH}$ and soluble solids / titratable acidity ratio indicate that there is greater genetic variability for these characters, revealing the possibility of genetic gains through mass selection. In addition, by performing visual selection for longitudinal and cross-section diameters, genetic gains can be obtained by indirect selection in characteristics fruit and pulp mass and fruit volume, as they have high, positive and significant correlations with fruit diameters. 
Table 3. Mean, standard deviation (SD) and coefficient of variation (CV) for colorimetric components of jabuticaba tree accessions.

\begin{tabular}{|c|c|c|c|c|c|c|}
\hline \multirow{2}{*}{ Accessions } & \multicolumn{3}{|c|}{ Peel } & \multicolumn{3}{|c|}{ Pulp } \\
\hline & $\mathrm{L}$ & $a^{*}$ & $b^{*}$ & $\mathrm{~L}$ & $\mathrm{a}^{*}$ & b* \\
\hline 1 & 25.64 & 1.81 & 0.24 & 21.61 & 2.79 & 3.43 \\
\hline 2 & 23.70 & 6.30 & 1.99 & 28.81 & 4.67 & 11.43 \\
\hline 3 & 23.68 & 4.51 & 1.38 & 32.02 & 1.24 & 10.96 \\
\hline 4 & 25.30 & 3.67 & 1.32 & 26.93 & 3.07 & 9.67 \\
\hline 5 & 26.47 & 2.25 & 0.59 & 23.20 & 5.85 & 4.95 \\
\hline 6 & 24.81 & 5.35 & 1.59 & 16.13 & 4.40 & 6.44 \\
\hline 7 & 22.53 & 4.52 & 1.03 & 25.49 & 8.88 & 10.74 \\
\hline 8 & 26.41 & 2.90 & 0.81 & 29.16 & 3.03 & 5.15 \\
\hline 9 & 24.81 & 4.13 & 0.93 & 26.30 & 6.94 & 8.38 \\
\hline 10 & 22.53 & 2.16 & 0.87 & 28.28 & 2.72 & 4.74 \\
\hline 11 & 25.96 & 3.09 & 0.88 & 20.45 & 4.62 & 3.55 \\
\hline 12 & 24.13 & 4.18 & 0.95 & 29.75 & 5.46 & 11.35 \\
\hline 13 & 24.69 & 4.30 & 1.02 & 32.31 & 4.09 & 11.83 \\
\hline 14 & 24.92 & 2.46 & 0.63 & 27.79 & 3.26 & 5.20 \\
\hline 15 & 24.87 & 2.48 & 0.77 & 27.91 & 1.92 & 4.86 \\
\hline 16 & 25.73 & 3.17 & 0.62 & 28.82 & 1.60 & 3.38 \\
\hline 17 & 26.33 & 4.97 & 1.33 & 19.04 & 6.94 & 9.06 \\
\hline Mean & 24.94 & 3.66 & 1.00 & 26.12 & 4.20 & 7.35 \\
\hline SD & 1.28 & 1.26 & 0.42 & 4.56 & 2.09 & 3.19 \\
\hline CV (\%) & 5.12 & 34.48 & 42.22 & 17.46 & 49.80 & 43.41 \\
\hline
\end{tabular}

Genetic divergence estimates

Genetic divergence estimates began with the analysis of all characters evaluated in fruits. According to the analysis of results, insignificant contribution variables were detected for the discrimination of divergence, which were eliminated, remaining the nine most important variables for genetic divergence discrimination (fruit mass, pulp mass, peel mass, number of seeds, longitudinal diameter, transverse diameter, volume, density and soluble solids), which are used for the formation of clusters, allowing obtaining more reliable and accurate results.

According to the physicochemical characteristics of fruits, the dissimilarity measure (Table not shown), estimated by the average Euclidean distance (D), showed that the greatest divergence is found between accessions 1 and $7(D=1.91)$, accessions 8 and 2 ( $D=$ 1.88) and accessions 1 and $17(D=1.83)$. The shortest distances were found between accessions 1 and 11 (D $=0.427)$, accessions 6 and $16(D=0.43)$ and accessions 2 and $12(D=0.47$ ), indicating that they are the most similar genotypes.

Through cluster analysis by the Tocher optimization method for quantitative characteristics, the 17 accessions were separated into six groups (Table 4).

Accessions (1, 11 and 10) were allocated to the first group, representing $17.65 \%$ of the total accessions characterized. The second $(6,16,17$ and 7), the third (2, 12, 3 and 13) and fourth groups (4, 14, 5, and 15) corresponded to $23.53 \%$ each. The fifth and sixth groups were represented by one access each, accessions 9 and 8 , respectively.

Table 4. Groups formed by the Tocher optimization method, based on the standardized average Euclidean distance.

\begin{tabular}{cc}
\hline Group & Accessions \\
\hline II & $1,11,10$ \\
III & $6,16,17,7$ \\
IV & $2,12,3,13$ \\
V & $4,14,5,15$ \\
VI & 9 \\
\hline
\end{tabular}

The number of groups formed shows wide variability among evaluated plants. According to Barros et al. (2005), groups formed by only one individual show that such accessions are more divergent in relation to the others, which makes them not to group with any other genotype. Danner et al. (2011) evaluated 16 characters of fruits from 36 native jabuticaba plants from different locations in southwestern state of Paraná and also observed wide variability among them.

Clustering using the nearest neighbor method based on the standardized average Euclidean distance allowed the elaboration of the hierarchical dendogram, and the cut was performed at $95 \%$ of the total genetic distance (Figure 1).

Thus, the formation of 5 groups was observed. Group I was composed of accessions (1 and 11). Group II comprised accessions (2, 12, 3, 13, 4, 14, 5 and 15) representing $47 \%$ of accessions. Group III was composed of accessions ( 9 and 10). Group IV was composed of 
accessions (6, 16, 7 and 17) and group $\vee$ (accession 8). Analyzing the genetic divergence of jabuticaba trees in naturally occurring sites in the state of Rio Grande do Sul, Zerbielli et al. (2016) observed the formation of six groups.

The smallest divergence occurred between accessions 1 and 11, both belonging to the same group in both analyses (Table 4 and Figure 1). Thus, the use of these individuals in controlled hybridization is not recommended, as it may lead to inbreeding depression, consequent loss of vigor by homozygosis and presence of deleterious genes (Miranda Filho, 2001).

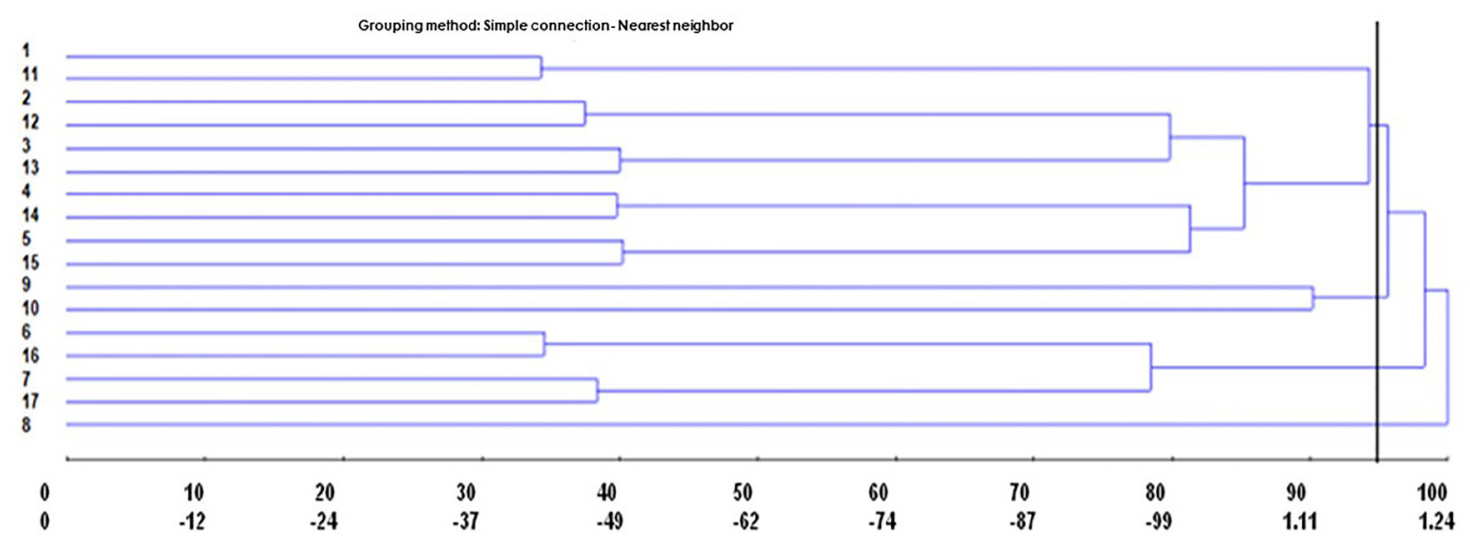

Figure 1. Tree diagram obtained by the nearest neighbor method based on the standardized average Euclidean distance.

For a breeding work, crossings between more distant accessions are indicated, that is, with greater genetic variability, as it will allow good alternatives for the use of heterotic effects. According to Cruz et al. (2014), knowledge about variability enables decision making with greater precision regarding conservation and management of this genetic material, which can be used for breeding programs.

Table 5 shows the relative contribution of the nine characters evaluated in the 17 genotypes in genetic dissimilarity. All characters contributed to the determination of genetic divergence, to a greater or lesser extent.

The characters that most contributed to genetic divergence were total soluble solids (13.18\%), fruit mass (12.24\%), peel mass (12.03\%), and pulp mass (11.77\%), in contrast, fruit density was the characters that contributed the least to genetic divergence, with only $8.82 \%$. The four characters of highest contribution together contributed with $49.2 \%$ of the total. Zerbielli et al. (2016) evaluated the genetic divergence among 40 jabuticaba tree genotypes based on 12 characters and found the highest contribution of the TSS / TTA ratio (41.56\%), followed by pulp percentage (25.76\%) and peel percentage (23.24\%), accounting for approximately $90 \%$ of the genetic divergence of jabuticaba tree genotypes. Danner ef al. (2011), among 36 jabuticaba tree genotypes based on 16 characters, observed the highest contribution of peel (48.0\%) and pulp percentage (45.5\%). These results demonstrate the importance of fruit mass and soluble solids content in genotype discrimination, being, therefore, variables directly linked to industrial yield and fruit production.

Table 5. Relative contribution of nine characters to divergence - SINGH (1981).

\begin{tabular}{ccc}
\hline Variable & Value (\%) & S.j \\
\hline Total soluble solids & 13.18 & 15783.7308 \\
Fruit mass & 12.24 & 14654.1226 \\
Peel mass & 12.03 & 14409.1736 \\
Pulp mass & 11.77 & 14093.3962 \\
Number of seed & 11.35 & 13590.6640 \\
Transverse & 10.82 & 12960.0790 \\
diameter & 10.61 & 12700.2960 \\
Fruit volume & 9.18 & 10987.4552 \\
Longitudinal & 8.82 & 10561.5508 \\
diameter & & \\
Fruit density & &
\end{tabular}

One of the alternatives to increase the efficiency of character selection is to evaluate correlated characters. According to Hallaver et al. (2010), correlation measured through correlation coefficient measures the degree of genetic or non-genetic association between two or more characters, which use is of great importance to maximize plant breeding efficiency. Cruz et al. (2014) highlighted that correlations quantify the possibility of indirect gains by selection in correlated characters and that low heritability characters have more efficient selection when performed over correlated characters.

There is a significant association between all fruit masses and diameters, in addition to fruit volume with diameters and pulp mass. No significant correlation was detected for soluble solids content and number of seeds (Table 6).

All significant correlations were positive, 
indicating constant proportionality among parameters fruit, peel, pulp and seed masses, longitudinal and transverse diameter, as well as fruit volume, that is, positive correlations among characters indicate that when performing selections to increase the mean of one character, there will be indirect selection to increase the mean of its correlated character. Thus, it could be inferred that the larger the fruit, the greater its volume, mass and diameter. The highest significant positive correlations were between fruit mass and fruit diameter and volume, with results greater than 0.90, indicating high correlation among these variables, and confirming that the higher the fruit mass, the larger the fruit.

The study of correlations among characters of agronomic interest is of great importance as it provides subsidies to the breeder because selection efficiency can be increased by using correlated characters (Silva et al., 2013). However, obtaining genetic gains and classifying superior genotypes are in many cases obtained together (Borges et al., 2011).

Table 6. Pearson correlation coefficient estimates among parameters fruit mass (FM), fruit volume (FV), longitudinal diameter (LD), transverse diameter (TD), total soluble solids (TSS), number of seeds (NS), pulp mass (PM) and peel mass (PeM).

\begin{tabular}{|c|c|c|c|c|c|c|c|c|}
\hline & $\mathrm{FV}$ & FD & LD & TD & TSS & NS & PM & PeM \\
\hline FM & $0.93^{* *}$ & 0.04 & $0.93^{* *}$ & $0.98^{* *}$ & -0.04 & 0.09 & $0.83^{* *}$ & $0.56^{*}$ \\
\hline $\mathrm{FV}$ & & -0.28 & $0.84^{* *}$ & $0.91^{* *}$ & 0.05 & 0.07 & $0.87^{* *}$ & 0.47 \\
\hline FD & & & 0.05 & 0.04 & -0.16 & -0.17 & -0.13 & 0.20 \\
\hline LD & & & & $0.96 * *$ & -0.08 & -0.05 & $0.76^{* *}$ & $0.56^{*}$ \\
\hline TD & & & & & -0.09 & 0.03 & $0.81^{* *}$ & $0.59 *$ \\
\hline TSS & & & & & & -0.41 & 0.22 & -0.28 \\
\hline NS & & & & & & & -0.3 & -0.0 \\
\hline PeM & & & & & & & & 0.18 \\
\hline
\end{tabular}

\section{Conclusions}

Descriptive analyses indicate that there is genetic variability for the characters studied in jabuticaba, highlighting the possibility of selection.

Accessions 4, 5, 7 and 12 have potential for in improvement programs aiming for productivity, based on the characteristics pulp mass and chemical quality.

From the based on correlation analysis, it is possible to infer that there are possibilities of direct and indirect gains for production determining characters and for the organoleptic characteristics of fruits.

The Tocher method and the "nearest neighbor" method allowed the identification of parents that will be used in future crossings in order to take advantage of the potential effects of heterosis.

\section{Acknowledgments}

The authors thank to CAPES, FAPEMIG, CNPq and MEC for the financial support.

\section{References}

Alezandro, M.R., Dubé, P., Desjardins, Y., Lajolo, F.M., Genovese, M.I. 2013. Comparative study of chemical and phenolic compositions of two species of jaboticaba: Myrciaria jaboticaba (Vell.) Berg and Myrciaria cauliflora (Mart.) O. Berg. Food Research International 54: 468-477.

Almeida Júnior, E.B., Chaves, L.J., Soares, T.N. 2014. Genetic characterization of a germplasm collection of cagaiteira, a species native to the cerrado. Bragantia 73: 246-252.

Barros, A.M., Faleiro, F.G., Karia, C.T., Shiratsuchi.
L., Andrade. R.P., Lopes. G.K.B. 2005. Variabilidade genética e ecológica de Stylosanthes macrocephala. determinadas por RADP e SIG. Pesquisa Agropecuária Brasileira 40: 899-909.

Borges, V., Sobrinho, F.S., Lédo, F.J.S., Kopp, M.M. 2011. Associação entre caracteres e análise de trilha na seleção de progênies de meios irmãos de Brachiaria ruziziensis. Revista Ceres 58: 65-772.

Citadin, I., Danner, M.A., Sasso, S.A.Z. 2010. Jabuticabeiras. Revista Brasileira de Fruticultura 32: 577-583.

Citadin, I., Vicari, I.J., Silva, T.T., Danner, M.A. 2005. Qualidade de frutos de jabuticabeira (Myrciaria cauliflora) sob influência de duas condições de cultivo: sombreamento natural e pleno sol. Revista Brasileira de Agrociência 11:373-375.

Costa, F.R., Pereira, T.N.S., Sudré, C.P., Rodrigues, R. 2009. Marcadores RAPD e caracteres morfoagronômicos na determinação da diversidade genética entre acessos de pimentas e pimentões. Ciência Rural 39: 696-704.

Cruz, C.D. 2006. Programa GENES- análise multivariada e simulação. Editora da UFV, Viçosa, Brazil. 175 p.

Cruz, C.D., Carneiro, P.C.S., Regazzi, A.J. 2014. Modelos Biométricos aplicados ao melhoramento genético. Editora da UFV, Viçosa, Brazil. 668 p.

Danner, M.A., Citadin, I., Sasso, S.A.Z., Scariot, S., Benin, G. 2011. Genetic dissimilarity among jabuticaba trees native to southwestern Paraná, Brazil. Revista Brasileira de Fruticultura 33: 517-525.

Danner, M.A., Citadin, I., Sasso, S.A.Z., Tomazoni, J.C. 2010. Diagnóstico ecogeográfico da ocorrência de jabuticabeiras nativas no sudoeste do Paraná. Revista 
Brasileira de Fruticultura 32: 746-753.

Galate, R.D.S., Mota, M.D.C., Gaia, J.M.D., Costa, M.D.S. 2012. Caracterização morfoagronômica de germoplasma de açaizeiro no nordeste paraense. Revista Brasileira de Fruticultura 34: 540-550.

Gomes, F.P. 2009. Curso de estatística experimental. Editora da ESALQ, Piracicaba, Brazil. 451 p.

Guedes, M.N.S., Rufini, J.C.M., Azevedo, A.M., Pinto, N.A.V.D. 2014. Fruit quality of jabuticaba progenies cultivated in a tropical climate of altitude. Fruits 69: 449458.

Hallaver, A.R., Carena, M.J, Miranda Filho, J.B. 2010. Quantitative genetics in maize Breeding. Springer, New York, USA. 664 p.

Lima, A.J.B., Corrêa, A.D., Alves, A.P.C., Abreu, C.M.P., Barros, A.M.D. 2008. Caracterização química do fruto jabuticaba (Myrciaria cauliflora Berg) e de suas frações. Archivos Latinoamericanos de Nutrition. Organo Oficial de la Sociedad Latinoamericana de Nutrición 58: 416421 .

Miranda Filho, J.B. 2001. Endogamia ou consaguinidade. In: Nass, L.L., Valois, A.C.C., Melo I.S., Valadares-Inglis, M.C. Recursos Genéticos e Melhoramento: Plantas. Fundação MT, Rondonópolis, Brazil. p. 629-648.

Moreira, R.M.P., Ferreira, J.M., Takahashi, L.S.A., Vanconcelos, M.E.C., Geus, L.C., Botti, L. 2009. Potencial agronômico e divergência genética entre genótipos de feijão-vagem de crescimento determinado. Semina: Ciências Agrárias 30: 1051-1060.

Moura, N.F., Chaves, L.J., Naves, R.V. 2013. Caracterização física de frutos de pequizeiro (Caryocar brasiliense Camb.) do cerrado. Revista Árvore 37: 905-912.

Moura, R.C., Lopes, P.S.N., Brandão Junior, D.S., Gomes, J.G., Pereira, M.B. 2010. Biometria de frutos e sementes de Butia capitata (Mart.) Beccari (Arecaceae), em vegetação natural no Norte de Minas Gerais, Brasil. Biota Neotropica 10: 415-419.

Perfeito, D.G.A., Carvalho, N., Lopes, M.C.M., Schmidt, F.L. 2015. Caracterização de frutos de mangabas (Hancornia speciosa Gomes) e estudo de processos de extração da polpa. Journal of Neotropical Agriculture 2: 1-7.

Rodrigues, S., Fernandes, F.A., Brito, E.S., Sousa, A.D., Narain, N. 2015. Ultrasound extraction of phenolics and anthocyanins from jabuticaba peel. Industrial Crops and Products 69: 400-407.

Salla, V.P., Danner, M.A., Citadin, I., Sasso, S.A.Z., Donazzolo, J., Gil, B.V. 2015. Análise de trilha em caracteres de frutos de jabuticabeira. Pesquisa Agropecuária Brasileira 50: 218-223.

Silva, D.F.P., Silva, J.O.C., Matias, R.G.P., Ribeiro, M.R., Bruckner, C.H. 2013. Correlação entre características quantitativas e qualitativas de frutos de pessegueiros na geração F2 cultivados em região subtropical. Revista Ceres 60: 53-58.
Silva, M.C., Souza, V.B., Thomazini, M., Silva, E.R., Smaniotto, T., Carvalho, R.A., Genovese, M.I., Favaro-Trindade, C.S. 2014. Use of the jabuticaba (Myrciaria cauliflora) depulping residue to produce a natural pigment powder with functional properties. Food Science and Technology 55: 203-209.

Singh, D. 1981. The relative importance of characters affecting genetic divergence. The Indian Journal of Genetics and Plant Breeding 41: 237-245.

Zenebon, O., Pascuet, N.S., Tiglea, P. 2008. Métodos físicoquímicos para análise de alimentos. Instituto Adolfo Lutz, São Paulo, Brazil. 1020 p.

Zerbielli, L., Nienow, A.A., Dalacorte, L., Jacobs, R., Daronch, T. 2016. Diversidade físico-química dos frutos de jabuticabeiras em um sítio de ocorrência natural. Revista Brasileira de Fruticultura 38: 107-116.

Conflict of Interest Statement: The authors declare that the research was conducted in the absence of any commercial or financial relationships that could be construed as a potential conflict of interest.

All the contents of this journal, except where otherwise noted, is licensed under a Creative Commons Attribution License attribuition-type BY. 